\title{
The Impact of Trade Deficit in Nepalese Economy
}

\author{
Ashmita Dahal Chhetri \\ Lecturer of Management \\ Thakur Ram Multiple Campus, TU \\ ashmitadahalchhetri@gmail.com
}

\begin{abstract}
The objective of this paper is to study and analyze the growth and direction of Nepalese foreign trade along with the causes and recommendations of trade deficit. Efforts have been made to sort out the principal sources of the trade deficit in Nepal. Landlockedness, political instability, lack of export diversification, devaluation of domestic currency, lack of resources, etc. are the major causes of the trade deficit in Nepal. Nepal, being not self-reliant on factors of production, consumer goods and capital goods, needs to import goods from abroad. On another hand, Nepal's exports are heavily concentrated; both in terms of product and destination. Nepal's major trading partners are India, China, U.A.E, etc. During the year 2019/20, Nepal exports goods worth RS. 97.71 Billion And import goods worth RS. 1196.80 billion Leading to a trade deficit of RS.1099.09 Billion. Trade deficit is acting as negative catalyst in the economic growth and GDP of a country. Increased deficit has caused suppressed inflation. Import to export ratio is continuously increasing as demand is increasing and these demands could not be met by the domestic producers. During the year 2019/20, the contribution of trade on GDP of Nepal is $40.65 \%$. No doubt, trade is an engine of economic growth. So, after analyzing barriers in the foreign trade, some of the steps to be taken are recommended which includes the development of competitive ability and enhancement of Human Resources, commodity and market diversification, formulation of strong legal framework and trade policy, incentives for the promotion of export and priority in the agricultural and hydropower sectors.
\end{abstract}

Keywords: Trade deficit, Impacts, causes, export, import, Nepal, recommendations

\section{Introduction}

The Nepalese economy has becomes a dependent economy after the adoption of globalization in Nepal. Nepal has entered into a trade agreement with many countries for import and export. Nepal has to import a variety of goods from abroad because of inadequate available resources, so, international trade has become the boon of globalization for developing countries like Nepal. In fact, International trade is the lifeblood of the global economy. All countries in the globe undergo the process of export and import. A country imports those goods or services which are not available in the country and exports those goods or services which are in excess supply in the country. In the era of today, international trade promotes economic development by bettering competitive capacity, expanding the market, and providing modern technology and machinery for the industrial and agricultural sector. We cannot deny the fact that it is also considered as engine of economic development as it has the potential to activate the sustainable and long term economic development. Until 1951 AD, Nepal's foreign trade was just restricted with India and Tibet. Soon after 1951, the trade relation extended with Japan, the USA, Germany, Malaysia, Singapore, Thailand, etc. Nowadays, foreign trade is expeditiously rising but with the increase in the total volume of trade, the trade deficit is also increasing (Kafle, 2017).

Nepal, being not self-reliant in factors of production, consumer goods and capital goods, international trade is very pivotal for economic prosperity. Foreign trade is one of the outstanding sources of foreign exchange earning which is necessary to import capital goods along with other consumer goods and services that are not produced locally. GDP of a country increases when there is trade surplus in contrary, if we consume more of the foreign goods in comparison to value of goods sold to foreigners, then trade deficit arises. In this regard, our GDP falls down.

\section{Background of the study}

Nepal, a small economy, having around 40.65\% (World Bank, 2020) of contribution by trade in its GDP in 2020AD, has been confronting a trade deficit since few years. In Nepal, trend of trade deficit is continuously increasing as it has very few goods to export. In 1980s, the majority of Nepal's exports were used to be raw 
materials, agro-based goods, handicrafts, Blankets, in large volume but low profitable value. However, after 1990s Nepal's exports have been shifted to manufactured parts to some extent. Import is increasing in comparison to the export. Enhancement in the purchasing power of people brought by the inflow of remittance has led to the increase in import of vehicles, electronic items, jewelry, and other luxurious items; however economic in-stability and feeling of insecurity has led to the decrease in export of commodities.

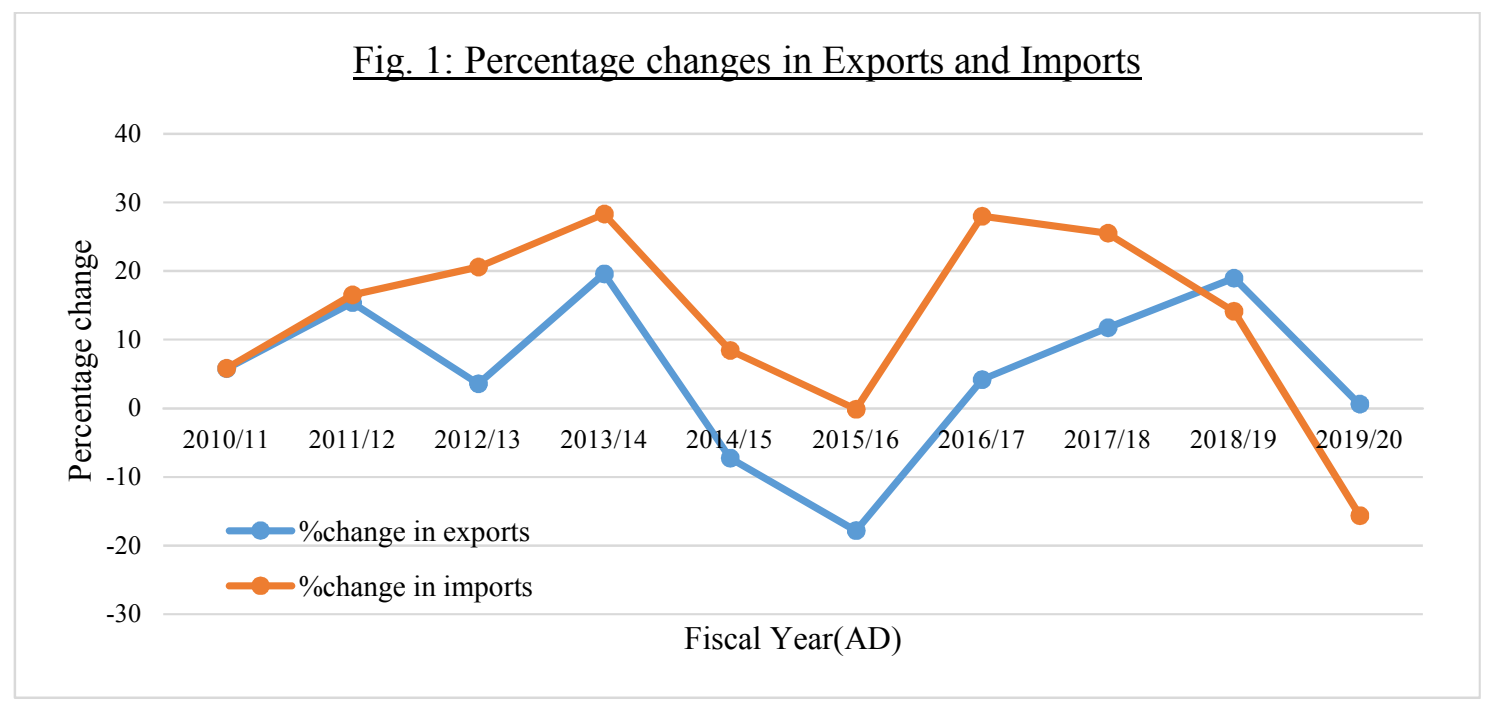

The amplifying and continued discrepancies between the level of export and import have produced a distressing level of trade deficit in Nepal. Diminishing growth in export compared to booming growth in import has become the matter of great concern for Nepal to benefit from Trade. Nepal is one of the most liberalized and trade dependent economies in the South Asia. The process of economic liberalization started in 1985 and started to accelerate after 1990. After becoming a member of World Trade Organization (WTO), Nepal continued to broaden the openness and pushed down tariff walls and other kinds of import restrictions.

\section{Statement of the Problem}

Nepalese foreign trade performance has so far been poor. Several factors seem tube responsible, and its landlockedness is one of the major causes for Nepal's weak production base, which is eventually linked with the growth of exports and imports of technology and raw material. Not only the open border with India but also the limited transit facilities in one or other way have constrained its trade with overseas countries. In Nepal, the trade deficit is continuously increasing because of very few goods to export. Most of the exports are of the raw material in nature with large volume and low profitable value. Although Nepal's export has changed from agriculture goods in the 1980s to manufactured goods after 1990s. As compared to imports, the rate of export is decreasing over time. The flow of remittance has increased the imports especially of vehicles, electronics, petroleum products, etc. whereas, instability and insecurity have decreased the export.

Furthermore, the abolishment of export quota in 2005 further worsened the trade gap. Nepal is one of the most liberalized and trade-dependent economies in South Asia. The process of economic liberalization started in 1985 and geared up after 1990. By 2004 (the year of WTO membership), Nepal continued to broaden the openness and pushed down tariff walls and other kinds of import restriction. However, when the domestic manufacturing sector is in its infant stage and the country is foreign resource dependent for development finance, the costs of liberalization may outweigh its benefits (Silwal, 2008). The growing and continued mismatch between import and export have resulted in an alarming level of trade deficit in Nepal. Over the years, export has almost been snagged, and the import skyrocketed (NPC, 2016). High cost of production complied with poor access to international market are some of the major constraints to expand Nepal's export base. Thus, Nepal's main issue of foreigntrade is increate are sing trade deficit even after various issues and policies.

- What are the causes of trade deficit in Nepal?

- What are the major importing and exporting goods of Nepal?

- How does the trade deficit impact in Nepalese economy? 
- What is the composition of Nepalese Foreign trade with its leading trading partner India, China, and other countries?

\section{Objectives of the Study}

The general objective of the study is to understand the trade scenario, import-export value, and the trade deficit of Nepal, and the specific objectives of the study are:

- To investigate the causes of trade deficit in Nepal.

- To analyze major importing and exporting goods of Nepal

- To study impacts of trade deficit in Nepal in different sectors.

- $\quad$ To understand the composition of Nepalese Foreign trade with its leading trading partner India, China, and other countries.

\section{Significance of the Study}

Foreign trade has significant role in the development of different sectors of the economy. The study provides the idea about trade and trade deficit. The main focus of the study is to understand the trade scenario, import-export value, and the trade deficit of Nepal. The study helps for the researcher, planners and others to it will help the researcher to get knowledge about the behavior of the economy and provide idea about trade and trade deficit decide about trade expansion. The government can check the effect between the trade deficit and gross domestic product, the effect between the trade deficit and trade volume redeficit and can improve its trade policy.

\section{Limitations}

However, the study has some limitations, which are as follows:

i. The study uses secondary data. So. It makes no efforts to conduct field survey

ii. The reliability of this study depends on the reliability of secondary data

iii. The study only covers the period from the year 2012/2013 to 2019/20 except for some studies which cover period from (2009/2010).

iv. The findings of this study cannot be generalized to all developing countries because ofdiverse characteristics.

\section{Literature Review}

Nepal is encountering a consistent trade deficit throughout the decades. For certain economist, trade deficit, alone isn't an issue. They contend that if an economy makes a major venture or when individuals devour more than they broadly produce, a trade deficit happens. In any case, long term trade deficit in any economy can't be seen as a positive sign. An economy can scarcely sustain a continuous trade deficit that has been seen in Nepal. Actually, a huge part of the expansion in the trade deficit is clarified by the remittances. External sector of Nepal is accurately incapable with constantly expanding trade deficit. Export engaged on flooding inthe ongoing years and imports stayed unstable. In spite of the factthat the development pace of exports out-placed that of imports, trade deficit extended for the most part because of relative biggervolume of imports (R \& Sharma, S. K. 2002). The import additional ventures and export oriented businesses may push the nation to come out of the persistent trade deficit. Trade deficit has been mostly financed by remittance inflows, along these lines thevolume and indication of current record is generally dictated by volumes of imports and remittance from abroad.

After 1951 AD, Nepal's trade relation expanded with many other countries of the world like Japan, USA, Germany, Malaysia, Singapore, Thailand, Kuwait, France, Bangladesh, Spain etc. Nepal's foreign trade is rapidly increasing but with the increase in the total volume of trade, the trade deficit is also increasing (Kafle, 2017). The growing and continued mismatch between import and export have resulted in an alarming level of trade deficit in Nepal. Over the years, export has almost been snagged, and the import skyrocketed (NPC, 2016).High cost of production complied with poor access to international market are some of the major constraints to expand Nepal's export base.

Acharya (2019) using descriptive method found that very low export performance of Nepal is creating the problem of rapidly increasing trade deficit. Nepal is also unable to diversify its trade in terms of countries and 
commodities.

Kafle (2017) examined the trends in Nepalese foreign trade and found major reasons for trade deficit. He believed that foreign trade plays a very important role in the economic development of a country. It promotes economic development by improving competitive capacity, expanding market, and providing modern technology and machineries for industrial and agricultural sector.

\section{Research Methodology}

This study is descriptive in nature. It is based on secondary data. In understanding the trade scenario, importexport value, and the trade deficit of Nepal, data have been collected after the liberalization of international trade in Nepal. The time period selected is from 2012/13 to 2019/20. Since the study is based on secondary sources, data have been collected from the various publications of the Ministry of Finance, journals, governmental reports, institutional websites, newspapers, articles, and documents. Based on the problem, issues, and objectives, detailed information has been collected to describe and analyze the research objectives. The research is based on quantitative data. The description of the situation of the Nepalese foreign trade and trade deficit is all in quantitative data. Simple statistical tools: ratios, percentage, trend line and time bar-chart have been used to analyze data.

\section{Exports}

Nepal is a less developed country in Southern Asia. Nepal's exports are hugely concentrated; both in terms of product and destination. Hence, export diversification has become a goal of national development strategy of Nepal since the implementation of the Third Five Year Plan; 1965-70 (Nepal Planning Commission, 2016). However, limited exportable items and trade dependency, particularly with India, continue to remain a burning challenge for the Nepalese economy. On April 23, 2004, with the purpose of integrating Nepalese economy with the regional and global trading systems, Nepal joined the multi-lateral trading platform WTO (World Trade Organization, 2016) and entered into two regional trade agreements-Agreement on South Asian Free Trade Area (SAFTA) and Bay of Bengal Initiative for Multi-Sectoral Technical and Economic co- operation (BIMSTEC) Free Trade Agreement.

Owing to similar socio-economic condition and access to sea through India only, India has become major trading partner of Nepal. However, in the last four decades, Government of Nepal has taken several measures to diversify its trade and this has led to decrease the heavy dependency on India and increases in the shares of countries other than India. The trade relation of Nepal expanded with many other countries after the downfall of tyrannical Rana regime and introduction of Democracy. During the Fiscal Year 2009/10, total export was equivalent to RS. 60.95 Billions. It gradually increases up to 2014 AD. During the F/Y 2013/14 total amounts of export was RS. 91.36 Billions, and falls for certain years. During the F/Y 2019/20, total value of goods exported from Nepal touches RS.97.71 Billion. Nepal exports goods and products to worth RS.70.11. Billion to India which is $71.75 \%$ of the total export. Nepal's export since 10years is graphically presented as follows:

\section{Export Trade of Nepal with India, China and Other countries (Values in NRs. Billions)}

\begin{tabular}{|l|l|l|l|l|l|l|l|l|l|}
\hline Countries & $\mathbf{2 0 1 1 / 1 2}$ & $\mathbf{2 0 1 2 / 1 3}$ & $\mathbf{2 0 1 3 / 1 4}$ & $\mathbf{2 0 1 4 / 1 5}$ & $\mathbf{2 0 1 5 / 1 6}$ & $\mathbf{2 0 1 6 / 1 7}$ & $\mathbf{2 0 1 7 / 1 8}$ & $\mathbf{2 0 1 8 / 1 9}$ & $\mathbf{2 0 1 9 / 2 0}$ \\
\hline India & 49.62 & 51 & 59.61 & 55.87 & 39.5 & 41.45 & 46.72 & 62.73 & 70.11 \\
\hline China & - & 2.09 & 2.84 & 2.23 & 1.68 & 1.7 & 2.44 & 2.11 & 1.19 \\
\hline Others & 24.65 & 23.83 & 29.54 & 27.23 & 28.94 & 29.9 & 32.2 & 32.27 & 26.41 \\
\hline Total Exports & $\mathbf{7 4 . 2 7}$ & $\mathbf{7 6 . 9 2}$ & $\mathbf{9 1 . 9 9}$ & $\mathbf{8 5 . 3 3}$ & $\mathbf{7 0 . 1 2}$ & $\mathbf{7 3 . 0 5}$ & $\mathbf{8 1 . 3 6}$ & $\mathbf{9 7 . 1 1}$ & $\mathbf{9 7 . 7 1}$ \\
\hline
\end{tabular}

Table 1: Export trade of Nepal with India, China, and Others (Value in billion)

Source: (Nepal Rastra Bank, Economic Bulletin and indicators, 2020; Nepal Foreign Trade Statistics 2019/20) 


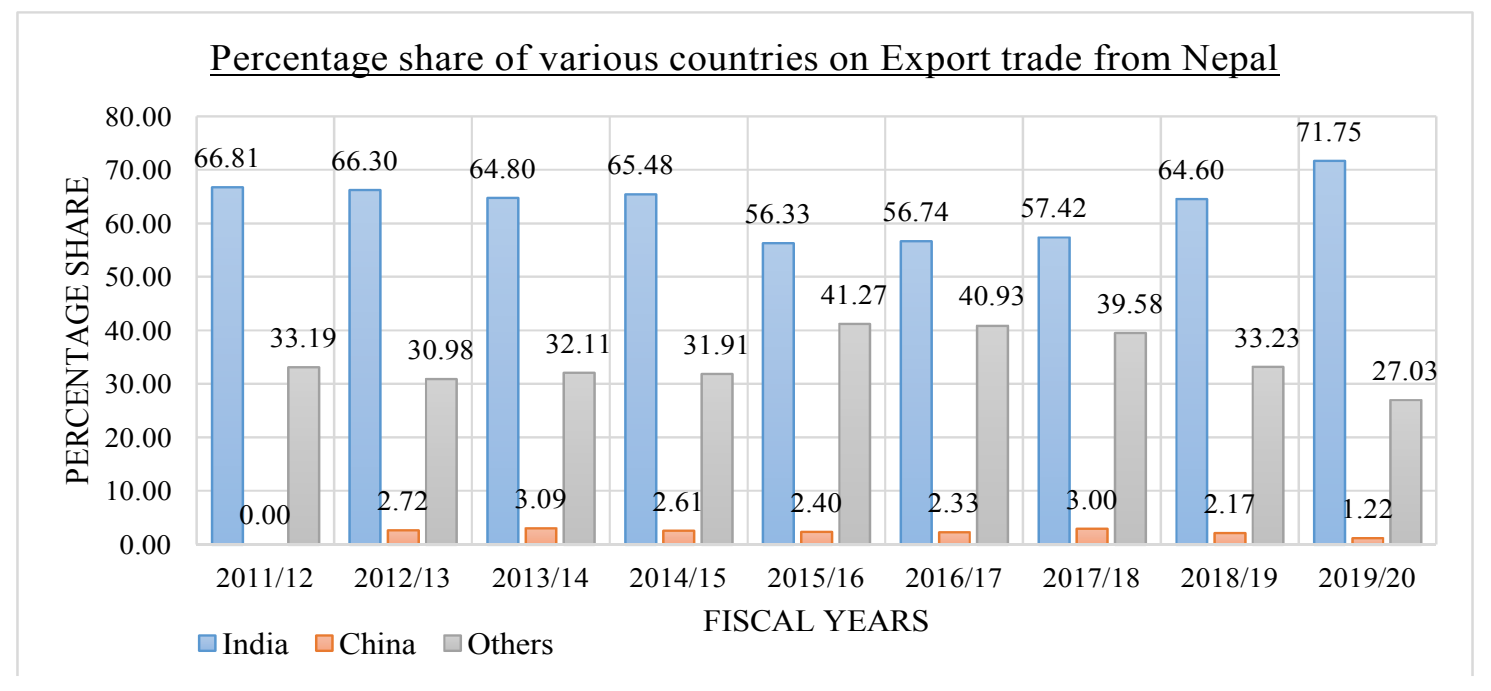

Figure 2: Percent share on total exports.

Source: (Nepal Rastra Bank, Economic Bulletin and indicators, 2020)

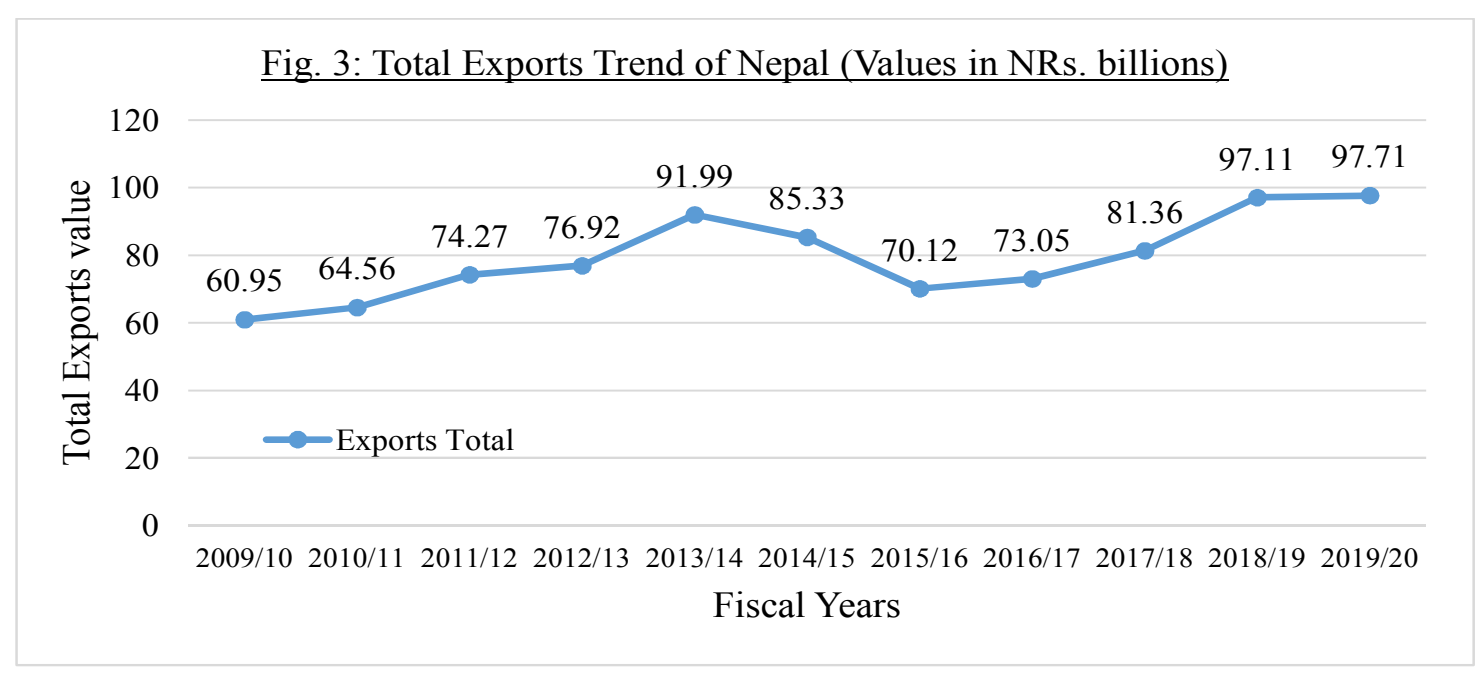

Nepal mainly exports woolen carpets, beverages, textiles, tea, jute product, and readymade garments. With the growth of carpet and garment industries, the country's merchandise trade balance has improved to some extent. Its main export partners include India, US, Germany, Turkey, UK etc. which is shown in figure below.

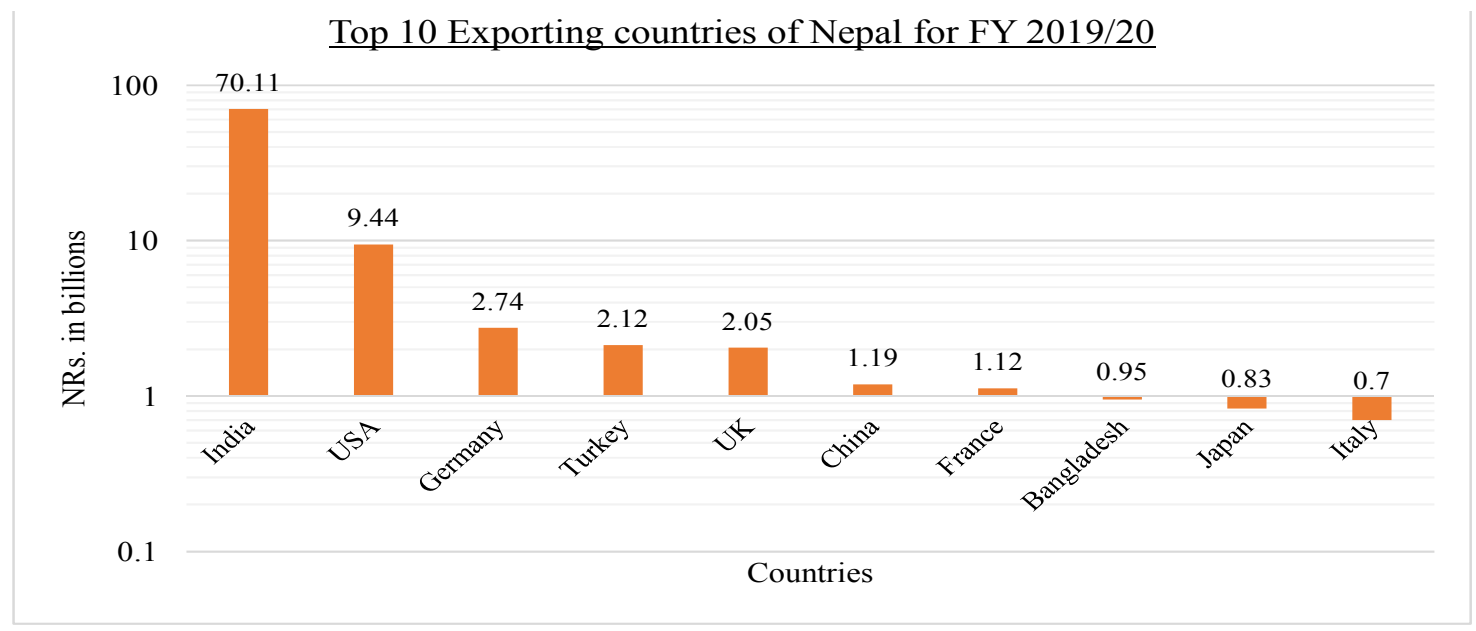

Figure 4: Top 10 exporting countries of Nepal- FY 2019/20 


\section{Imports}

Imports in Nepal averaged 44,934.88 Million NRs. from 2001 until 2020, reaching an all-time high of 1,41,240.60 Million NRs. in September of 2018 and record low of 8,000.30 Million NRs. in October of 2001 (Trading Economics, 2020). Because of the expanding population with the increased number of demands and consumptions, import is increasing very rapidly. During the year 2009/10, total value of goods imported was only NPR. 375 Billions, while during the year 2018/19, import is nearly 4 times of 2009/10 i.e. NPR 1,418 Billion ad in year 2019/2020, import is 1196.8 billion. Trend of import is shown graphically as follows:

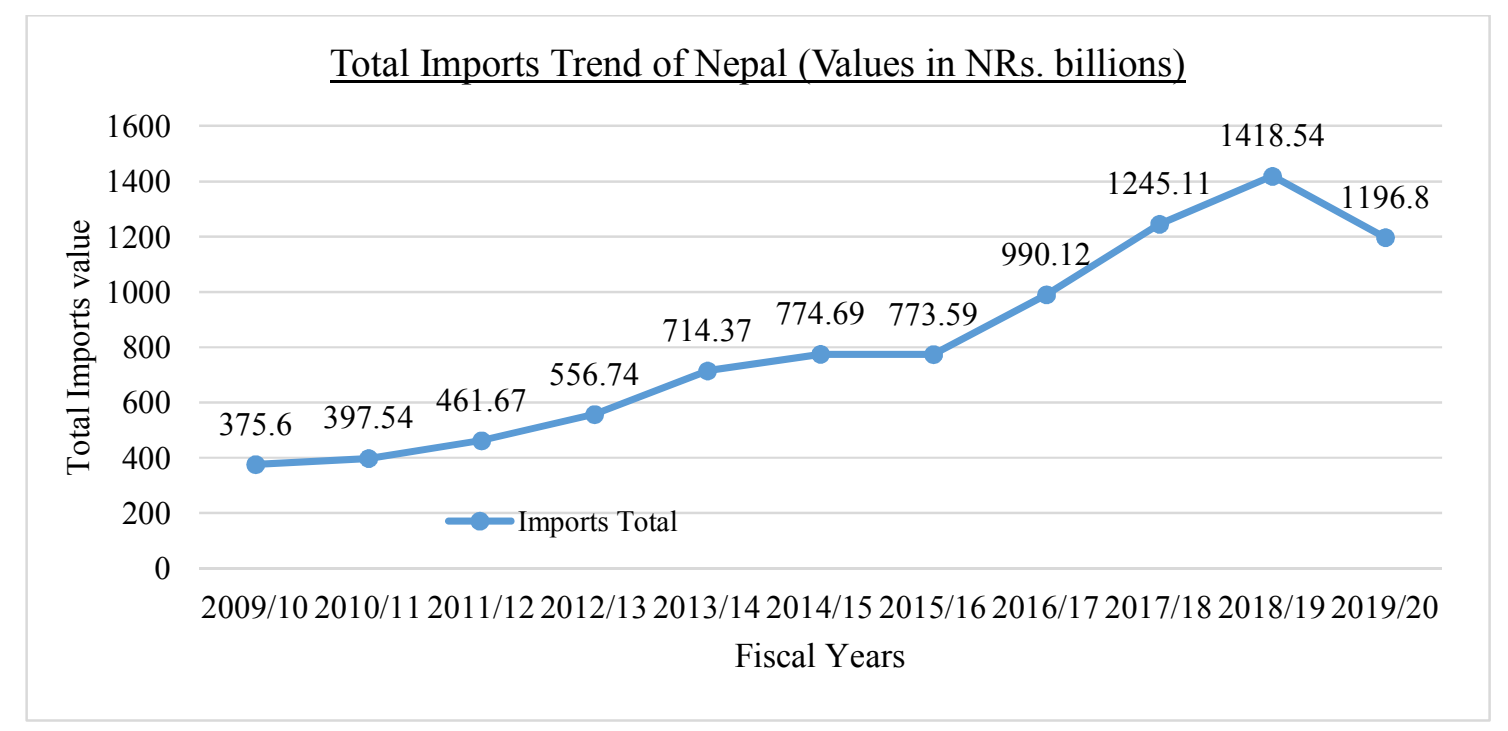

Figure 5: Imports Trend of Nepal

Source: (Trade and export promotion Centre, 2020)

Ratio of import to export is high is Nepal due to low domestic productivity arising from Labor problems and failure to promote import substitution industrialization. The TEPC's (Trade and Export Promotion Center) statistics shows that the ratio of the country's imports to its exports stands at 14.61:1. The ratios in the fiscal years 2019/20 and 2018/19 were 12.25 and 14.61 respectively.

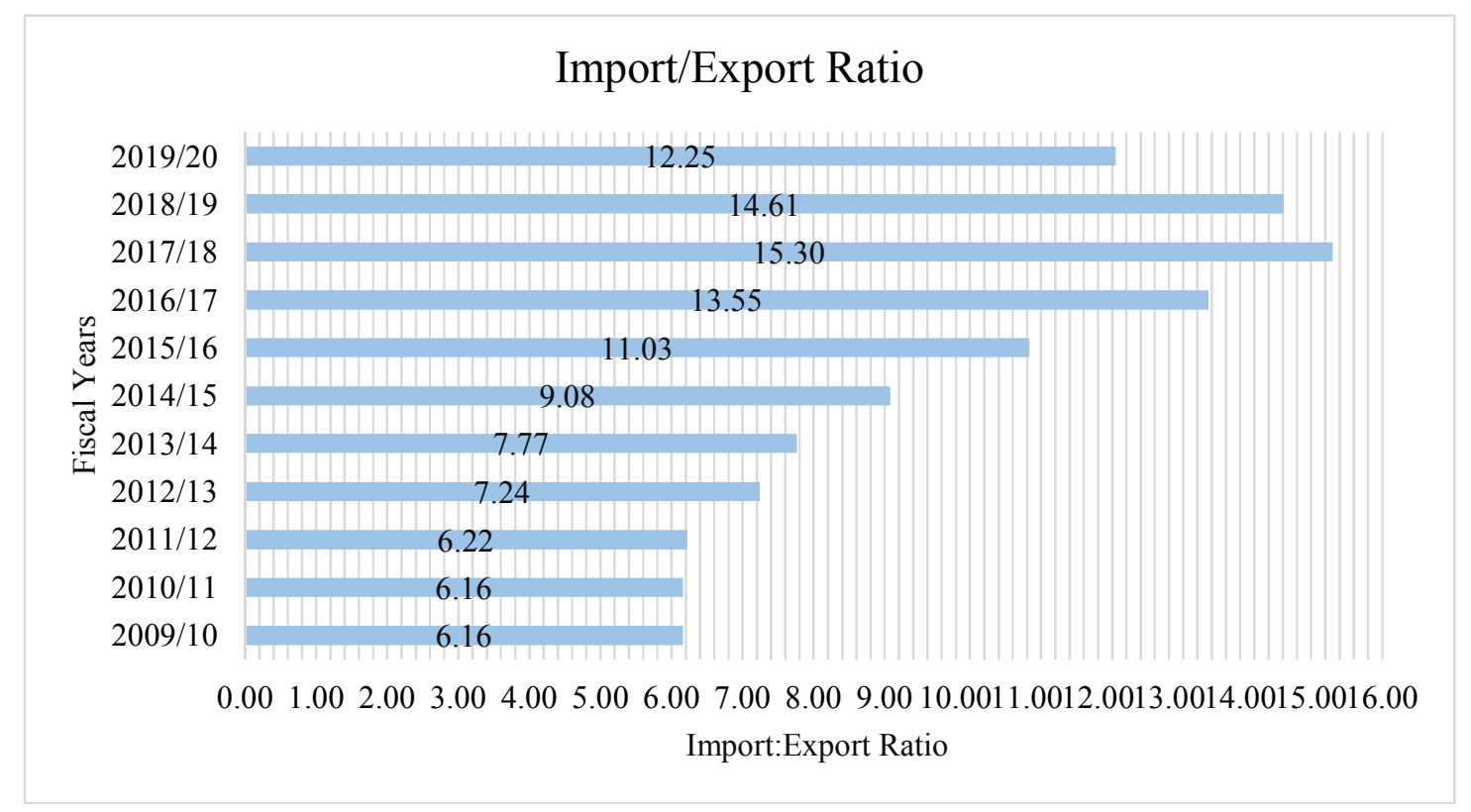

Figure 6: Import-Export ratio 
The above chart indicates that Nepal is forced to divert an enormous block of its foreign exchange reserves earned from other sources such as remittance and tourism to pay for imported goods. Nepal, being surrounded by India on three sides, India has always become a major importing partner to Nepal since long back. Each year, more than $60 \%$ of the goods are imported from India.

\begin{tabular}{|l|l|l|l|l|l|l|l|l|l|}
\hline \multicolumn{7}{|c|}{ Import Trade of Nepal with India, China and Other countries (Values in NRs. Billions) } \\
\hline Countries & $\mathbf{2 0 1 1 / 1 2}$ & $\mathbf{2 0 1 2 / 1 3}$ & $\mathbf{2 0 1 3 / 1 4}$ & $\mathbf{2 0 1 4 / 1 5}$ & $\mathbf{2 0 1 5 / 1 6}$ & $\mathbf{2 0 1 6 / 1 7}$ & $\mathbf{2 0 1 7 / 1 8}$ & $\mathbf{2 0 1 8 / 1 9}$ & $\mathbf{2 0 1 9 / 2 0}$ \\
\hline India & & & & & & & & & \\
\hline China & 299.39 & 367.03 & 477.95 & 491.66 & 477.21 & 633.67 & 814.1 & 917.91 & 805.4 \\
\hline Others & - & 62.45 & 73.32 & 100.17 & 115.69 & 127.25 & 159.99 & 205.53 & 183.11 \\
\hline Total Imports & 162.28 & 127.26 & 163.1 & 182.86 & 180.69 & 229.2 & 271.02 & 295.1 & 208.29 \\
\hline
\end{tabular}

Table 2: Import trade of Nepal with India, China, and Others (Value in billions)

Source: (Nepal Rastra Bank, Economic Bulletin and indicators, 2020)

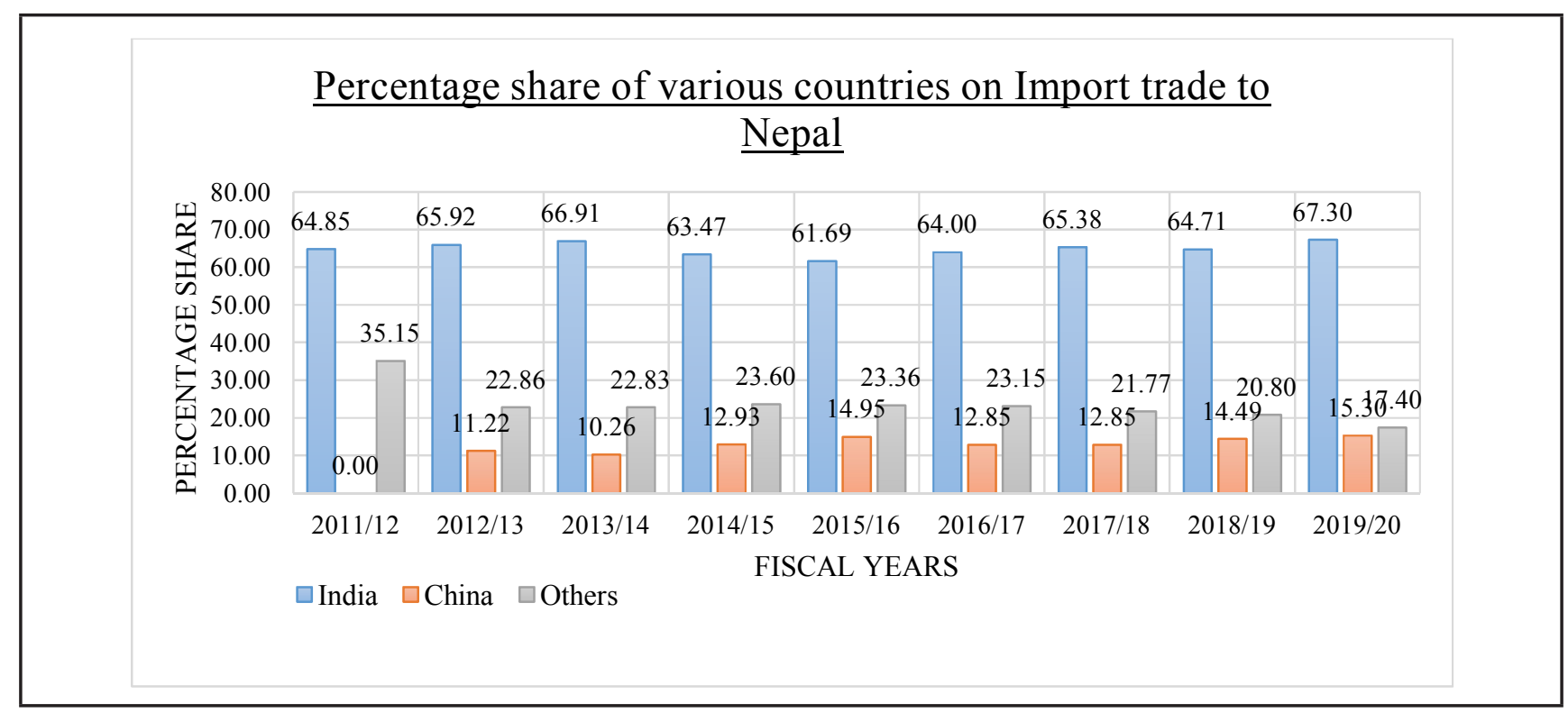

Figure 7: Percent share on total imports

Source: (Nepal Rastra Bank, Economic Bulletin and indicators, 2020)

Nepal chiefly imports oil, gold, iron and steel, clothes, pharmaceutical products, cement, electronic appliances, food and vehicles. Its main import partners include India, China, US, Indonesia, UAE, Canada etc. which is shown in figures follows:

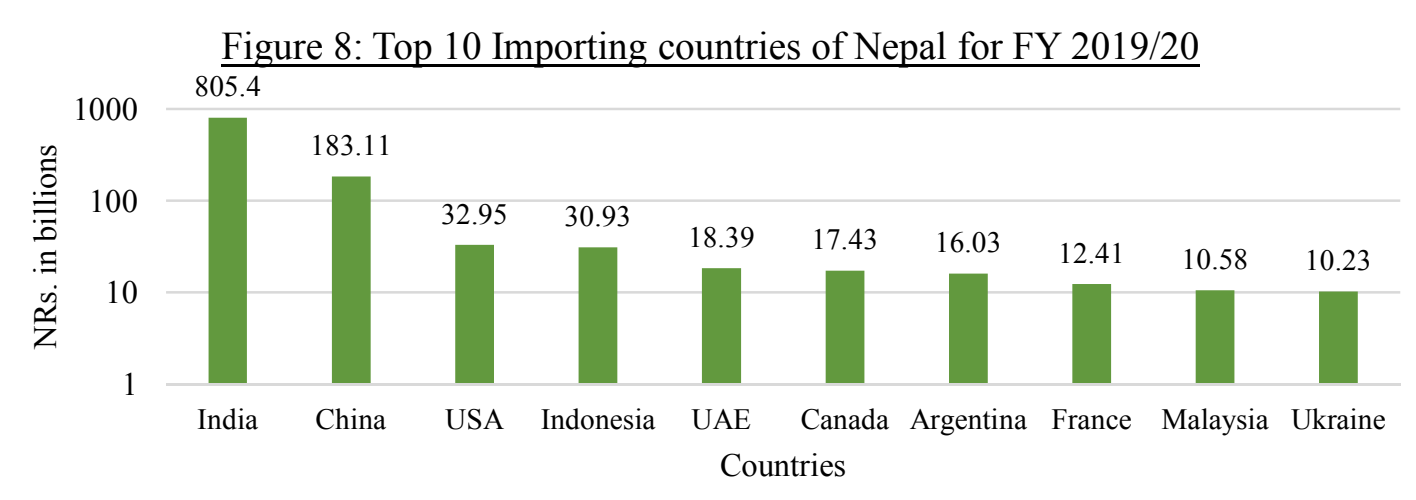




\section{Remittance}

After the signing of labor agreement with many countries, Remittance has become one of the determining sources of external finances for Nepal. Remittance assists in improving the living standard of people and diminishing poverty in the country. However, it might cause an ill situation in the trade balance. With the inflow of remittance in the country, the purchasing power of the people increases because of higher disposable income. Ultimately, the aggregate demand for consumable goods and other goods also increases, leading to an increase in imports.

\section{Figure 9: Total Remittance vs Total Trade Deficit in last 15 years}

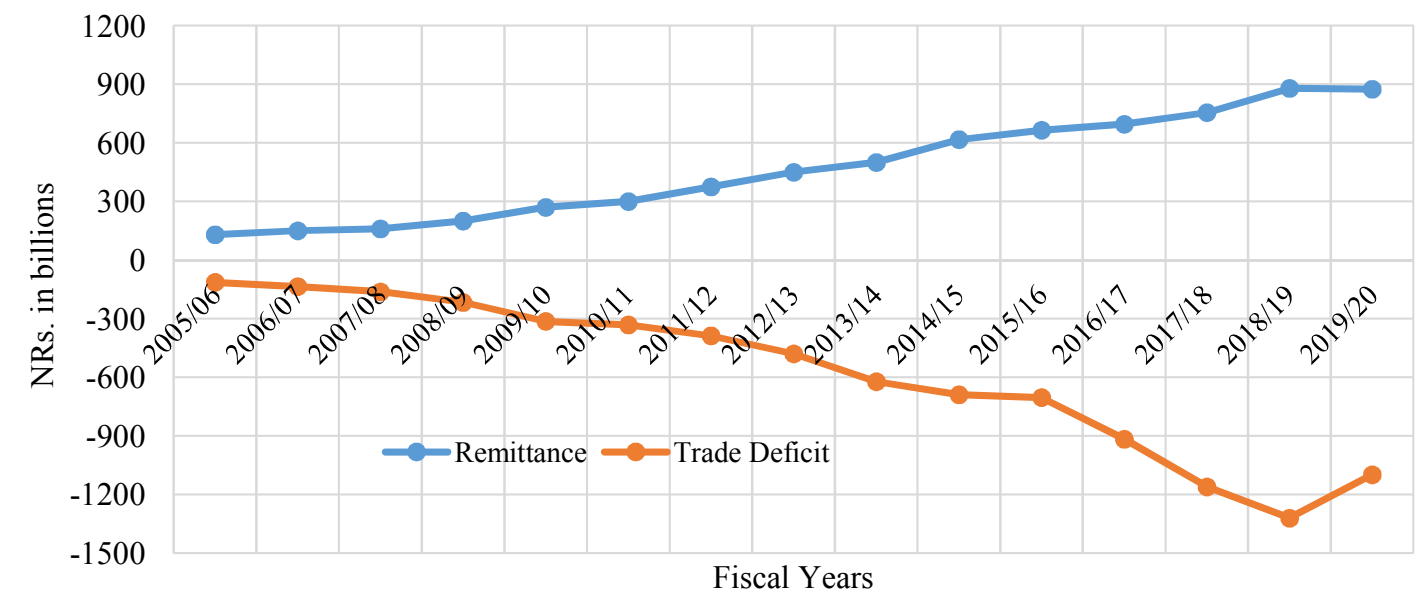

\section{Contribution of Trade on GDP of Nepal}

Trade is decisive to developing and least-developed (LDCs) for a variety of reasons. Essentially, it is often the dominant mechanism for attaining the benefits of globalization. Countries triumph when they gain market access for their exports and new technology through international transfers, and when heightened competitive pressure improves the allocation of resources. Participation in external trade provides number of benefits to the developing countries. They may achieve benefit through resource allocation according to comparative advantage. The profiteering of economies of scale and enhanced capacity utilization; modernization in technology; increases in domestic savings and foreign direct investments; and raised employment (Balassa, 1989). Trade has vital role in GDP and economic growth of nation.

Nation's balance of trade is positively affected by exports and adversely affected by imports. A trade surplus is a positive balance of trade, and trade deficit is a negative balance of trade. Due to the balance of trade being notably added to the computation of the nation's gross domestic product using the expenditure method, trade surpluses are contributions and trade deficits are "drags" upon their nation's GDP; however, foreign made goods sold (e.g., retail) contribute to total GDP (Bureau of Economic analysis, 2020).

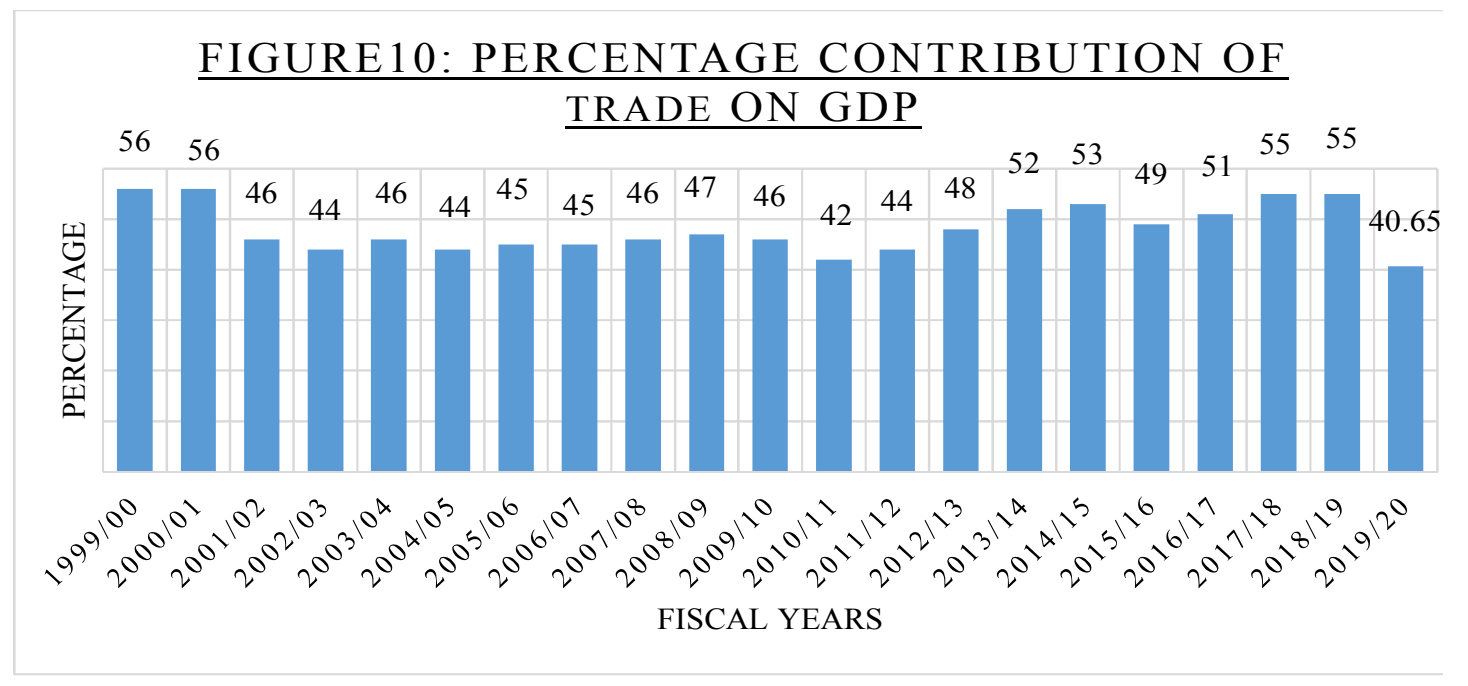


The trade to GDP ratio is an indicator of the importance of External trade in the economy of a country. It is used as an index of the openness of a country to external trade. During the year 2019/20.

\section{Trade Deficit}

Trade deficit, simply, is the amount by which cost of a country's imports exceeds the value of imports. Trade deficit is also called as Negative Balance of Trade.

Mathematically, Trade deficit = Value of goods imported - Value of goods exported The trade "balance" of a region shows the difference between what it earns from its exports and what it pays for its imports. If this value is in negative i.e. the total value of goods imported by a region is more than the total value of goods exported by that region, then it shows the condition of "trade deficit". A trade deficit means generally can mean two thingsFirstly, that the demand in the domestic economy is not being fulfilled by the domestic producers. Secondly, deficit implies the lack of competitiveness of the local industry (Udit Misra, 2019). Because of low export performance, Nepal is fronting the complication of rapidly increasing trade deficit. Nepal is also unsuccessful to broaden its trade in terms of countries and commodities. Owing to rising imports of goods over slower exports, country's trade deficit has been expanding for a long time. Due to current adoption of double-edged policy of substituting imports and increasing exports by Nepal government, the growth rate of merchandise import has been falling and export part has been improving. But, while going through the trade history of Nepal, Nepal has never been in trade surplus. Trade deficit has always been a shadow of Nepalese trade economy. Implications of trade deficit depend on impacts of production, employment, and how the deficits are financed. Nepal's import, export and trade deficit of last 10 years is graphically presented as below:

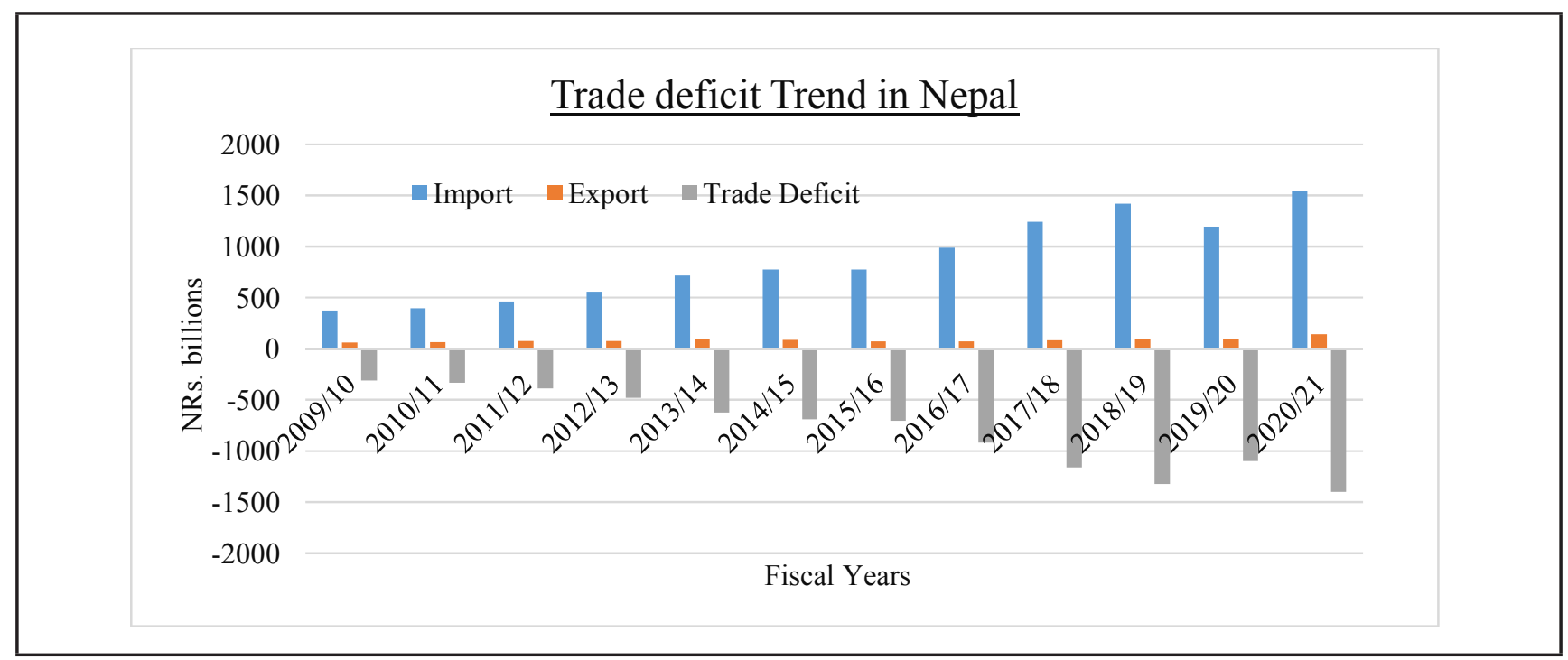

Figure 11: Trade deficit trend of Nepal

Source: (Trade and Export Promotion Centre, Glimpse of Nepal's foreign trade, 2020)

\section{Causes of Trade Deficit in Nepal}

There are a number of causes for Trade deficit in Nepal. Efforts have been made to outline the theoretical framework on the basis of following determinants. These are discussed as below:

Geographical structure. Strategically, Nepal is located between two economic powerhouses; India in the East, West, and South and China in the North. Owing to landlocked geography, it has become able to export a limited number of goods only, while the import is far more. It is not directly connected with the sea route because of which it has to encounter trade barriers and so, lag behind the maritime neighbors in overall development and external trade. Due to the expensive freight and transportation cost, import cost also appears high. Owing to its Landlockedness, Nepal is in fragile condition for the reason of low trade in the global market.

Low-Quality Goods. The greed of middle-class farmers has encouraged them to use a higher amount of pesticides than recommended which has resulted in the agricultural products being toxic and poor quality. Many of the manufacturing industries do not use the ingredients in the proper mix leading to product deterioration. Due to such acts and carelessness of the domestic goods and service providers, Nepalese have been haunted by the 
thought that domestic goods are not of good quality to use. So, even Nepalese people are attracted towards the western fashionable goods. All these have an impact on overall external trade.

Lack of resources. Nepal has to face scarcity of various resources like materials, capital, machinery, etc. With the available resources Nepal cannot produce goods to the extent which could serve even to its entire population. So, excess requirement needs to be imported. There is also a shortage of semi-skilled and highly skilled manpower in Nepal which hampers the pace of recovery and growth. Due to a lack of resources, an adequate amount of goods could not be produced domestically and it has to go through the external trade leading to the trade deficit.

High Cost of Production. Most of the raw materials are imported from abroad. Procurement cost is high in the import due to the involvement of transportation cost, custom duty, insurance in transit, bank charges, incidental costs and so on. Wages paid to the labor is also high. Similarly, other overhead is also high. All these expenses lead to an increase in cost of production. Nepalese economy is small. Due to low demand/consumption, quantities cannot be produced in bulk for which it cannot enjoy the benefit of economies of scale. Ultimately, the cost per unit of goods is high in comparison to the same goods that can be imported from abroad. As the goods imported from foreign seems to be cheaper, Nepal has to import goods from foreign.

Lack of publicity and advertisement. In the context of Nepal, it lacks marketing, publicity and advertising campaign. Nepal produces various peculiar products that carry traditional and cultural values that include handicraft goods, sweaters, and woolen clothes. Pashmina shawl is a popular brand all over the world. Despite having such branded items, Nepal doesn't advertise about the features, quality, price etc. of its products in the international market because of which export of such items is low.

Devaluation of Currency. The devaluation of currency of the nation leaves negative impacts on trading. It makes export cheaper and import relatively expensive. Inelastic demand of import and export would cause further raise in trade deficit because of devaluation. If the home currency value depreciates, then the value of import will increase and that will become heavy burden for trade balance of the country. Moreover, the depreciation of the domestic currency leads to higher cost in purchasing goods and services from foreign countries. Simply, we can say, trade deficit increases as the value of home currency falls down.

Political instability. The bothering reason of political situation in Nepal genuinely impacts on import and export factor. It influences the domestic market of the nation. The local market could not compete with outside markets because of political instability. Political stability is more crucial than economic freedom in stabilizing the balance of payments. Nepal's political condition is so unbalancing.

\section{Impacts of Trade Deficit on Nepalese economy}

Trade surplus are no assertion of economic health, and trade deficits are no guarantee of economic weakness. Nepal is one of the economically struggling sovereign nations. The trade deficit is rising at an annual average rate of at least $13 \%$, which warns that if not adequately offset by export promotion or import substitution, will double in the next few years and quadruple in a decade. Even if we had a very effective strategy and institutional arrangements in the nation, enough researched market studies and cautiously identified potential export products that have both comparative and competitive advantages which, say, are able to offset the deficit of at least $\$ 2$ billion per annum, it will take at least a decade only to bisect the imbalance (Achyut Wagle, 2018). Some impacts brought by Trade Deficit on economy are described as; Impact of Trade Deficit on National Income.

Using the expenditure approach, National income can be represented as follows: (Investopedia, 2019) National Income $=\mathrm{C}+\mathrm{I}+\mathrm{G}+(\mathrm{X}-\mathrm{M})$

Where, $\mathrm{C}=$ Consumer spending on Goods and Services; $\mathrm{I}=$ Investor spending on Business Capital Goods; $\mathrm{G}=$ Government spending on Public Goods and Services; $\mathrm{X}=$ Exports;

$\mathrm{M}=$ Imports

If value of imports exceeds value of exports, there arises a negative impact on the value of national income. So, trade deficit reduces the national income.

Impacts of Trade Deficit on Gross Domestic Product. Trade deficit is impacting on GDP of Nepal. Trade surplus helps in increasing GDP, while in contrary trade deficit decreases GDP of a nation. The negative results on GDP arise because of exceeding import demands over export earnings. Large growth in trade deficit results in decreasing demands of overall domestic goods and services. Balance of trade is one of the aspects of a country's GDP. If domestic consumers spend more on foreign products than domestic producers sell to foreign consumers, 
trade deficit occurs. If maximum of the consumer demands is met by the export, it means domestic producers are not capable enough to satisfy domestic demands. Similarly, trade deficit brings inflation in the economy which causes loss of aggregate demand. Trade deficit leads to loss of jobs in home-based industries, may contribute to regional decline, and structural unemployment problems. All these cause slower real GDP growth.

Impact of Trade deficit on Interest rates. The countries with more trade deficits usually have higher interest rates than those with surplus or balanced trade (Batra \& Beladi, 2013). High interest rate tends to lead to a reduction in net exports (Exports-Imports). And negative exports means trade deficit.

Interest rate is also increased to prevent the domestic currency from being devalued and ultimately increases the value of Exports leading to reduce in Trade deficit. On the other hand, trade deficit rises inflation in the county of import. Inflation can be controlled by reducing money supply in the economy. Interest rate is increased to reduce money supply. So, in general, and being skeptic on cause and effect, it can be said that a tendency towards balance of payments deficit might commonly co-exist with interest rates being higher than would otherwise be the case.

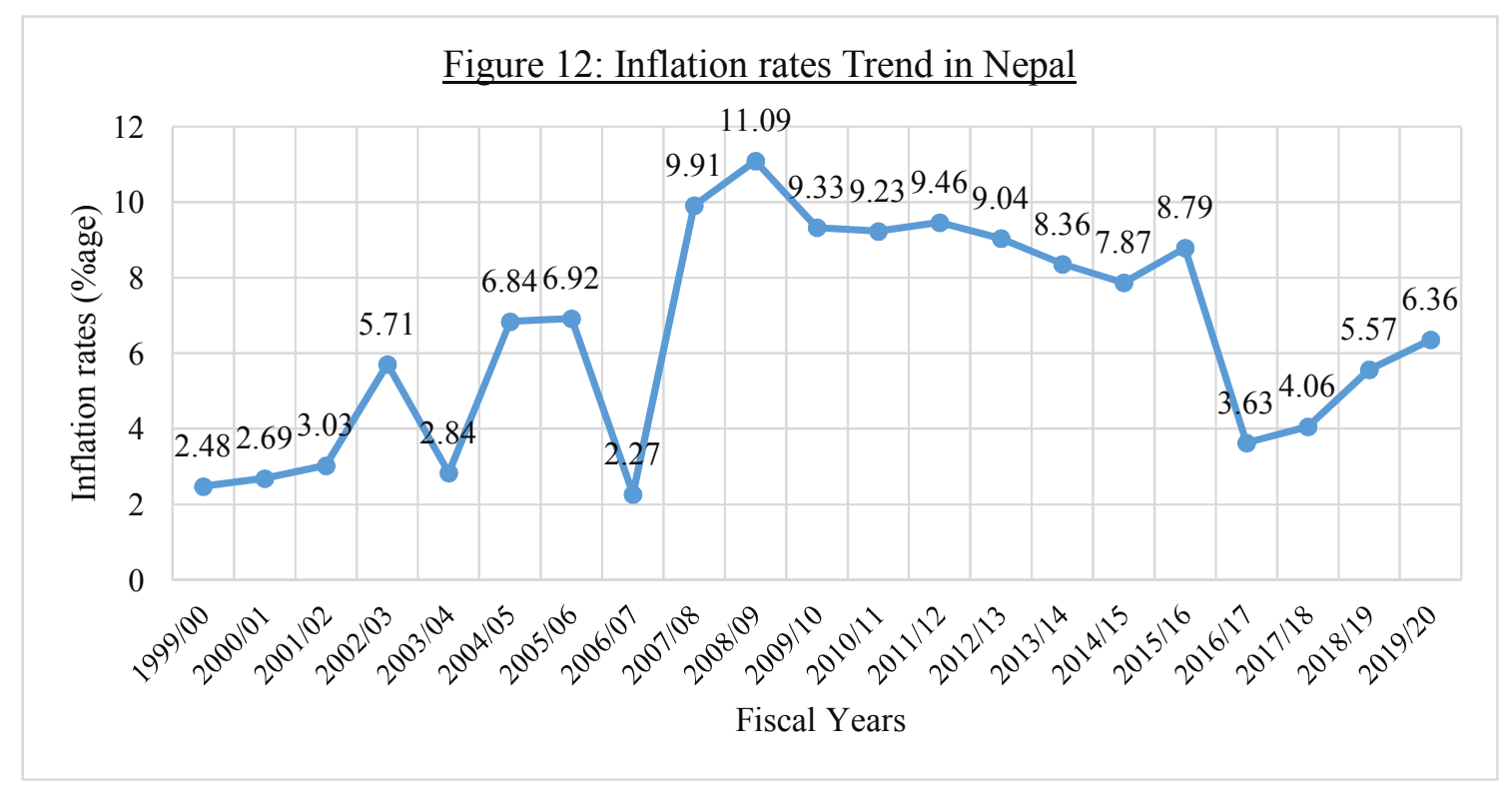

Impact of trade deficit on Price of commodities. Increasing deficit is a sign of suppressed inflation, as domestic consumption and investment overtake the growth in the economy's productive capacity. Domestic demand/ consumption is higher than the supply/production of domestic producer, then goods or services are imported. According to (Pettinger, 2017), rise of import causes a depreciation of home currency which ultimately tends to increase inflationary pressure because;

- Imports become more expensive

- Exports and AD increase causing demand-pull inflation

- With more competitive exports, firms have less incentive to cut costs

Likewise, import cost is high due high transportation cost, insurance cost, incidental cost and other factors. So, trade deficit leads the price of commodities to be high.

Impact of Trade deficit on Employment. Nepal has trade deficit of RS.1099. 09 Billion, during the year 2019/20. Nepal's jobs and wealth are being given to other countries that have taken advantage of Nepal for years. The philosophy of this argument is that if Nepalese buy goods from foreign rather than domestically, it will cause greater demand abroad and jobs will shift where the goods are produced, leading to less employment in the country with trade deficit. 


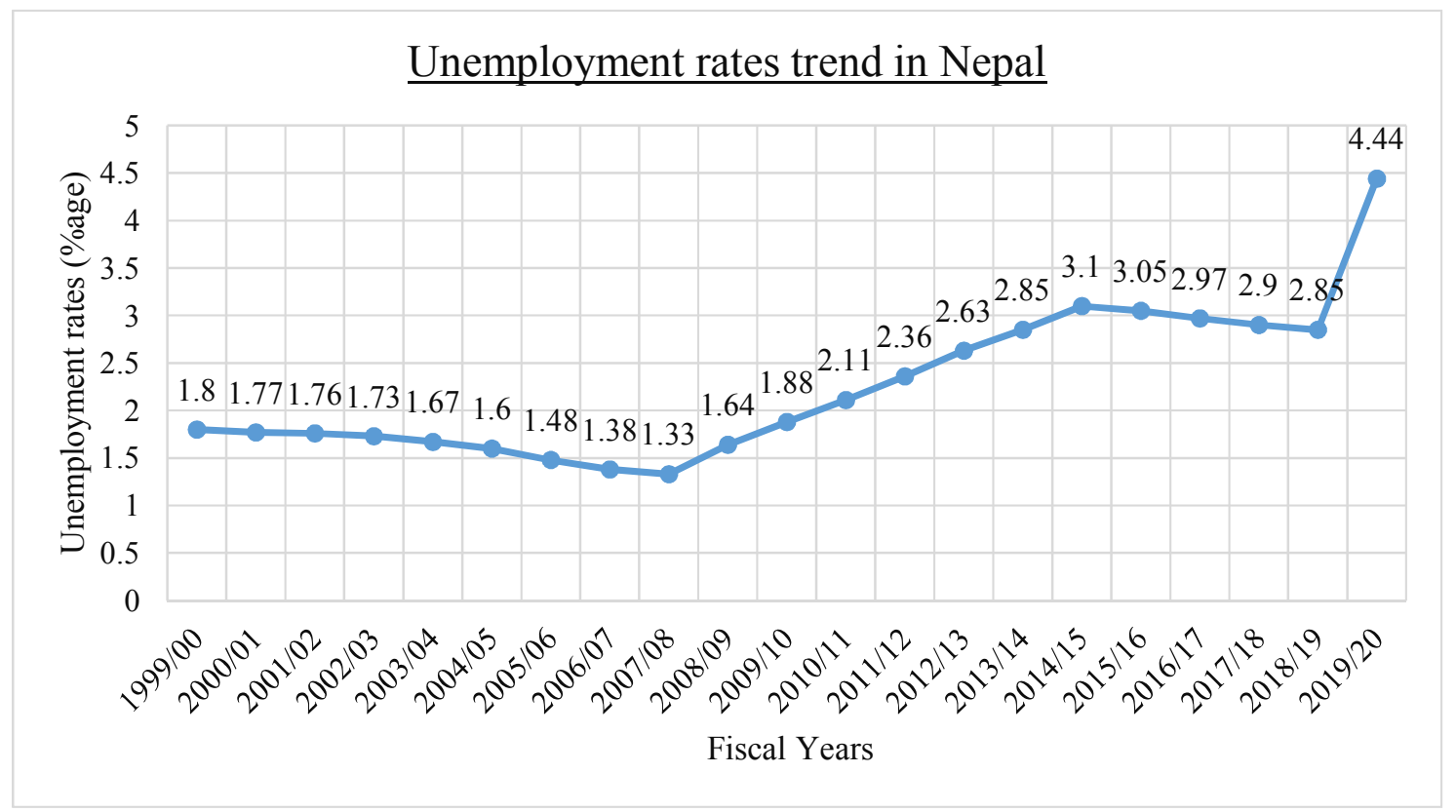

Figure 13: Unemployment Rate of Nepal

Source: (Statistics, 2020)

\section{Recommendation}

In globalize economy, Nepal cannot remain on segregation. Now, Nepal has trade relation with many countries of the world. Nepalese foreign trade trends and framework seems not so concrete. Gradually, increment of trade deficit shows that Nepalese trade is dominated by imports. To link the expanding trade gap, Nepal must act to expand production of local products, provide grants to the farmers, create conducive environment for the establishment of industries and rationally exploit the trade facilities. Nepal must formulate strict law against the production of goods not maintaining the standards, exploiting child as labor, and breach of contracts so that the global market could trust Nepal, and procure products without any suspicion. Analyzing all the barriers in the foreign trade, this study has some suggestions for the promotion and expansion of Nepal's foreign trade especially exports trade and ultimately economic growth of a country. Some of the suggestions are provided for incorporation in the trade promotion of Nepal as below:

\section{Competitive Ability and Enhancement of Human Resources}

In the modern era of globalization, Nepal needs to be competitive in the global level for which it holds some competitive advantage. Nepal does not possess comparative advantage in the sector of economies of scale, cutting-edge technology, marketing strengths, efficient production, and distribution systems but holds advantage on cheap labor. So, building of such human resources is the key for grabbing opportunities in the market. In the recent past of Nepal, human resource has become the key to success in International trade. Three areas could be identified in the context of Nepal:

- There is a need to enhance capacities in product innovation.

- Promotion of marketing skills

- Enhancement of trade-related expertise, analytical skills, and negotiating skills to the personnel of public sector.

\section{Commodity and Market Diversification}

Heavy dependence on a few low-value exports like Readymade garments and carpets has created hurdles in enhancing trading opportunities. Adequate efforts should be made to cut back export concentration ratio or to develop new areas of products or services that could be exported to the international market. There is absence of export diversification in case of Nepal. Nepal has not taken sufficient steps to develop products, identify product market and establish a link between product and market. Though the objective of product and market 
diversification has been indicated in plan documents as well as various policies issued by government time to time, it has not been disbursed in an efficient manner. Hence, this can be a vicinity where immediate steps should be taken to face the worldwide competition.

\section{Co-ordination of trade with Development Strategies and Safeguards Arrangement}

There is a need to coordinate trade and development strategies. No doubt, open economy is favorable to protectionism (practice of defending a country's domestic industries from foreign competition by taxing imports), free trade without any safeguards could lead a country to calamity, as has been demonstrated by the East Asian and the Latin American crisis. In this context, appropriate safeguards are recommended.

\section{Strong Legal Framework and New Trade Policy}

Nepal does not possess a durable, flexible and legal framework for administering trade. The Export-Import Control Act 1957 was initiated fundamentally with the motive of controlling or prohibiting the export or import of restricted items. Moreover, this act, in the present context, seems to have lost its significance as hardly anything has been mentioned about the process of registration of export-import agencies, export promotion, sharing of information, finance, export incentives, institutional arrangements and dispute settlement (Nepal Law Commission, 2006). Therefore, this act needs to be amended, taking into consideration its uniformity with WTO provisions. Or else, a separate foreign trade act should be formulated and enacted, for making import and export more systematic by fixing and reinforcing existing acts and regulations. Furthermore, Trade policy of 1992 has been outdated in the present context of globalization and liberalization. It is critical to bring new trade policy.

\section{Development of Export Processing Zone}

An EPZ is an industrial area especially designed for export-oriented industries and it provides the facility of tax exemption on imports of raw materials needed by the manufacturers inside the region. However, the manufactured goods are not allowed to be sold in the country. Even in 1990, five products were identified which could be produced by the industries inside the EPZ: carpets, garments, leather-based products, electric and electronic goods, products based on herbs... However, almost fifteen years have passed, and there is no sign of the creation of an EPZ yet. It is crucial that the government takes necessary steps immediately to formulate relevant laws for establishment of EPZs, and measures should be initiated to set up EPZs at appropriate locations (Pant, 2005).

\section{Reliable Trade Data and Periodic Reviews}

There is scarcity of knowledge on market information, pricing, quality, and level of competition, among others. Similarly, reliable data on trade are lacking as the figures published from one institution is different from the opposite institution. The proposed Nepal Trade Promotion Organization could be entrusted with this task of creating commodity-wise database relating to investment, production, imports and exports, among others. Timely review of performance of the country in both regional and foreign markets need to be undertaken in order to maintain the country's export thrust. Periodic policy analysis should be conducted by all relevant stakeholders in order to minimize the inherent gap between policy formulation and implementation with agreed time frames. This will enable the adoption of the corrective measures to be timely executed.

\section{Priority on Agriculture and Hydropower}

The corporate deficiencies, tax arrangement, corruption, and the small size of the market are prohibiting Nepal in fixing its problems in the trade sector. That is why, the country needs to specialize in the areas in which it can gain a competitive advantage. Nepal should step its foot on agriculture, small \& cottage industries and hydropower projects. Emphasis should be to chop the import of products which can be produced in Nepal, such as rice, grains, fruits, vegetables, etc. For instance, all things left balanced, just unquestionably reducing the import of agricultural products and by reducing petroleum imports (and substituting it with domestic hydropower) could cut Nepal's deficit to some extent. If the agricultural sector commences to become competitive to the point of being ready for export, the deficit can be reduced even more (Jagadish Prasad Bist, 2019).

\section{Conclusion}

The slow development in export contrasted with the vigorous development in import stays a significant distress for Nepal to gain profit in terms of trading. The overall development in export was $4.2 \%$ in the most recent decade though development in import during a similar period was 18.2 percent. India has been continuously involved majorly on the biggestexport target of Nepalese products and enterprises with engrossing 66 percent of 
total Nepal's export. In spite of being one of the largest and powerful country, China consumed $2.8 \%$ of Nepal's complete export averagely over recent years though it tends to berising consequently. Nations except India and China assimilated very nearly a fourth of the total export throughout the last decade. Woolen carpets, readymade garments, pashmina involved practically $50 \%$ of the all-out exports to different nations.

Nepal lacks in a lot of modern technologies that leads to industrialization growth, in recent history, Nepal has gradually moved from agriculture sector to service sector, there is a gap in industrialization growth. Therefore, Nepal does not have well- equipped industrial cores leading to the lack of quality products, making our products uncompetitive in global market. Low capitalformation is another problem for foreign trade that stops theforeign economic activities. Like we mentioned that Nepal does not have well- equipped bases and modern infrastructures this lacks potential environment for local as well as foreign investment leaving the nation dependent on internal investment with low capital foundation for expansions and growth. All reasons combined, it is sad to say that Nepal lacks skillful laborers, education and knowledge about modern technologies so to have the competitive advantage.

Though Trade is reckoned as the engine of economic growth, there still exists a huge gap between the objective and vision. The country still depends on a relatively small bucket of exports and a few destination markets. Unmanaged infrastructure and a lack of suitable business environment fueled by heightened political instability are the primary reasons for improper industrialization in Nepal. Consequently, domestic industries have not been able to capitalize the opportunity disclosed by robust growth in domestic demands. Nepal is an agricultural country, produces and exports only primary goods and raw materials. Nepal mainly exports Pashmina products, carpets, cereals, jute etc. and imports petroleum products, vehicles, machineries and so on. A nation with Trade deficit spends more on import than it earns on exports. But over time, continuous trade deficit weakens domestic industries and decreases job opportunities. So, trade deficit needs to be reduced to the minimum possible extent. Until and Unless, Nepal increases trade competitiveness formulating and adopting different policies, Nepal cannot reduce ever- increasing trade deficit. Export diversification has also become demand of time.

\section{REFERENCES}

Achyut Wagle (2018, August 7). Trade deficit. Retrieved from The Kathmandu Post: https://kathmandupost.com/ money/2018/08/07/trade-deficit

Balassa, B. (1989). The importance of trade for developing countries. Directions in the World Economy, 3-31.

Batra, R., \& Beladi, H. (2013). The US trade deficit and the Rate of Interest. Review of International Economics, 614-626.

Benjamin J. Loecken . (2018, February 10). Nepal extravagant Import tax. Retrieved from Grass root News: http://grassrootsnews.tv/2018/02/10/why-nepal-has-the-highest-vehicle -Import-tax-in-the-world/

BureauofEconomicanalysis. (2020, September3).Methodologies.RetrievedfromBureau of Economic analysis: https://www.bea.gov/resources/methodologies\#national_meth center, T. a. (2019, May 30). Foreign Trade Balance of Nepal. Retrieved from Trade and export promotion centre: https://www.tepc.gov.np/

Pant, Bhubanesh (2005, August 1). NRB archives. Retrieved September 6, 2020, from archive nrb: https://archive. nrb.org.np/ecorev/pdffiles/vol17_art5.pdf

Investopedia. (2019, August 28). Expenditure method. Retrieved from Investopedia: https://www.investopedia. $\mathrm{com} /$ terms/e/expenditure-method.asp

Investopedia. (2019, August 28). Expenditure method. Retrieved from Investopedia: https://www.investopedia. $\mathrm{com} /$ terms/e/expenditure-method.asp

Jagadish Prasad Bist. (2019, November 2). Nepal reliance on agriculture for trade deficit reduction. Retrieved September7, 2020, from TheKathmanduPost : https://www.kathmandupost.com/columns/2019/11/02/to reduce-the-trade-deficit-nepal-has- to-rely-on-agriculture

Kafle, A. (2017). Nepal's foreign trade: present trends. International Journal of Latest Engineering and Management Research (IJLEMR), 2(11), 1-7.

Kenton, W. (2019, June 25). Multi-fiber arrangement. Retrieved from Investopedia: https://www.investopedia. com/terms/m/multi-fiber-arrangement.asp 
Macro trends. (2020, July 31). Nepal inflation rate. Retrieved from Macro trends: https://www.macrotrends.net/ countries/NPL/nepal/inflation-rate-cpi

Maps of World. (2019, August1).PrimeministersofNepal.RetrievedfromMapsofWorld: https://www.mapsofworld. com/list-of/prime-ministers-nepal/

Nepal Carpet Manufacturer and Exporter Association. (2018, November 11). History of Carpet. Retrieved from Nepalcarpet.org: https://nepalcarpet.org/history-of-carpet/

Nepal Law Commission. (2006, November 24). Export and Import Control Act 1957. Retrieved September6, 2020, from Law commission: http:/www.lawcommission.gov.np/en/archives/category/documents/ prevailing- law/statutes-acts/export- and-import-control-act-2013-1957

Nepal Planning Commission. (2016, December3).Periodical plan.RetrievedfromNational planning commission: https://www.npc.gov.np/en/category/periodic_plans/12

Nepal Rastra Bank. (2019, July 31). Annual report. Retrieved from Nepal Rastra Bank: https://www.nrb.org.np/ contents/uploads/2020/08/Annual-Report-2017.18.pdf

Nepal Rastra Bank. (2020, April 31). Economic Bulletin and indicators. Retrieved from NRB: https://www.nrb. org.np/contents/uploads/2019/12/Macroeconomic_Indicators_of_Nepal- 2019- 11_November_2019new.pdf

Nepal, G. o. (2019, May 30). Foreign trade balance of Nepal. Retrieved August 28, 2020, from Trade and export promotion center: https://www.tepc.gov.np/

Nepal-India Chamber of Commerce and Industry. (2019, July 31). Trade statistics. Retrieved from NepalIndia Chamber of Commerce and Industry: https://www.nicci.org/pdf $/ 10 . \% 20$ Comparison $\% 20 \mathrm{of} \% 20$

Nepal's\%20Annual\%20Total\%20E xports\%20vs\%20Total\%20Import\%20of\%20Petroleum\%20 Products.pdf

New Business Age. (2019, May 28). Import of Vehicles. Retrieved from New business age: https://www. newbusinessage.com/Articles/view/10778\#: :text=Data\%20collected\%20fro m\%201989\%20to, as\%20 of $\% 20 \mathrm{FY} \% 202017 \% 2 \mathrm{~F} 18$.

Prussian, K. (2019, September 16). Export of Nepali Garment hits 13-year high. Retrieved August 31, 2020, from The Kathmandu Post: https://kathmandupost.com/money/2019/09/16/export-of-nepalireadymade-garment- hits-13-year-high

Silwal, R. (2008). The causes of trade deficit in Nepal. The Hague, Netherlands: Institute of Social studies (ISS).

Statistica. (2020). Nepal: Unemployment rate. Retrieved from Statistica: https://www.statista.com/ statistics/422507/unemployment-rate-in-nepal/

Sun koshi craft. (2019, September 23). Chandra Pashmina. Retrieved from Nepal fine Pashmina: http:// nepalfinepashmina.com/about-chyangra-pashmina

Tevin Pettinger. (2017, October 8). Imports and Inflation. Retrieved September 4, 2020, from Economics Help: https://www.economicshelp.org/blog/1491/economics/imports- and-inflation/

Trade and Export Promotion Centre. (2019, July 17). Export-Import databank. Retrieved from Trade and Export Promotion Centre: http://www.efourcore.com.np/tepcdatabank/commoditywise.php?txtmode=search

Trade and export promotion center. (2019, May 30). Foreign trade balance of Nepal. Retrieved from Trade and export promotion center: http://www.efourcore.com.np/tepcdatabank/

Trade and Export Promotion Centre. (2019, July 16). Hand knotted woolen product of Nepal. Retrieved from Trade and Export Promotion Centre: https://www.tepc.gov.np/major_products/full_content

TradeandExportPromotionCentre. (2019, July17).WoolenCarpet.RetrievedfromTrade and Export Promotion Centre: https://www.tepc.gov.np/major_products/full_content/hand-knotted-woolen-carpet-of- Nepal.

TradeandExportPromotionCentre. (2019, July17).Woolencarpets.RetrievedfromTrade and Export Promotion Centre: https://www.tepc.gov.np/major_products/full_content/hand-knotted-woolen-carpet-of- nepal

Trade and Export Promotion Centre. (2020, July 31). Glimpse of Nepal's foreign trade. Retrieved 
fromTradeandExportPromotionCentre: https://www.tepc.gov.np/pages/tepc- publication

TradingEconomics.(2020,August31).NepalImports. RetrievedfromTradingEconomics:https://tradingeconomics. $\mathrm{com} / \mathrm{nepal} /$ imports\#: :text=Imports\%20in\%20Nepal\%20averaged $\% 2044934.88$, NPR $\% 20 \mathrm{in} \% 20$ October\%20of\%202001.\&text=Nepal\%20Imports\%20\%2D\%20values\%2C\%20historical\%20data,updated $\% 20$ on $\% 20$ September $\% 20$ of $\% 202020$.

Udit Misra. (2019, November 6). Trade deficit. Retrieved from Indian Express: https://indianexpress.com/article/ explained/explained-what-is-trade-deficit-and-what- does-it-signify- 6104561/

World Bank. (2019). Trade (\% of GDP)-Nepal. Retrieved August 29, 2020, from World Bank indicator:https:// data.worldbank.org/indicator/NE.TRD.GNFS.ZS?end=2019\&locations=NP\&start=19 60\&view=chart

World Bank. (2020, September 02). Trading economics. Retrieved from trading economics: https:// tradingeconomics.com/nepal/trade-percent-of-gdp-wb-data.html

World Trade Organization. (2016, 07 29). WTO Membership. Retrieved from World Trade Organization: https:// www.wto.org/english/thewto_e/whatis_e/tif_e/org6_e.htm 